\title{
Viewpoint: The response of central North American prairies to seasonal fire
}

\author{
DAVID M. ENGLE AND TERRENCE G. BIDWELL
}

Authors are professors, Department of Plant and Soil Sciences, Oklahoma State University, Stillwater, Okla. 74078.

\begin{abstract}
Natural fires on the native grasslands of Oklahoma and Kansas were important for maintaining ecosystem structure and function. Today, land managers largely conduct prescribed fires in the late dormant season or they do not burn at all. When wildfires occur in other seasons, conventional wisdom assumes that desirable forage species for cattle are compromised. This assumption is based on a few fire studies limited in breadth and scope. To address this, we revisited numerous data sets to quantify the influence of season of fire on plant production and species composition. Research demonstrates that tallgrass prairie burned in the late spring starts growth earlier, grows more rapidly early in the growing season, and produces more tall grasses than unburned prairie. We contrast this response with the literature reporting the results of fire occurring in other seasons. Fire effects vary with fire frequency, fire-return interval, grazing history, herbicide use, successional stage, weather pattern, edaphic features, and topography. Our review of research suggests that a variety of responses to fire season are possible and rules-of-thumb that generalize responses are misleading. Most of the research on fire also does not report the interaction of fire and herbivory. Thus it is difficult to judge the influence of fire within the context of herbivory. Results from ongoing research suggest that the prairie is far more resilient under the interaction of fire and herbivory than earlier believed.
\end{abstract}

Key Words: native grasslands, prescribed fire, fire frequency, fire interactions, fire return interval, wildfire

Fire on the native grasslands of Oklahoma and Kansas, as in other portions of the Great Plains, provided a portion of the energy required for the development and maintenance of these grasslands (Bragg 1995). Natural fire was possible from late in the growing season before the first killing freeze in autumn, through the dormant season (i.e., after the first freeze in autumn and before the last freeze in spring), and up to several weeks after the last freeze in spring (Bragg 1982, Higgins 1986). The timing of fires with respect to season or within a season potentially influences plant species composition and productivity, and therefore influences rangeland management in the modern landscape. In this paper we demonstrate that a variety of plant species composition and production responses to season of fire are possible, and

Published with the approval of the Director, Oklahoma Agricultural Experiment Station through project S-1822.

Manuscript accepted 8 May 2000.

\section{Resumen}

En los pastizales nativos de Oklahoma y Kansas los incendios naturales han sido importantes para mantener la estructura y función de los ecosistemas naturales. En la actualidad, los adminstradores de pastizales realizan quemas controladas al final de la época de latencia, pero sin quemar la totalidad del pastizal. Cuando ocurren incendios sin control en otras epocas del año, las especies deseables para el ganado se ven seriamente afectadas. Sin embargo, esto ha sido sustentado en pocos estudios con limitada profundidad y duracibión. Para comprobar esto, se revisaron numerosos grupos de datos para cuantificar la influencia de la época de incendo en la producción y composión de las especies forrajeras. Las investigaciones en esta area han demostrado que los pastos altos quemados al final de la primavera, inician el crecimiento más temprano, mas rápido y con mayor producción al inicio de la época de crecimiento, que aquellos pastos altos que no son quemados. Comparamos esta respuesta con la informada en la literatura, sobre incendios ocurridos en otras epocas del año. Los efectos del incendio pueden variar con la frecuencia de incendio, intervalo de retorno del incendio, historia de pastoreo, uso de herbicidas, estado de sucesión, comportamiento climático, caracterisiticas edáficas, y topografia. Nuestra revisión sugiere que son posibles una variedad de respuestas a la época de incendio y reglas básicas que generalicen la respuesta han sido olvidadas. La mayoria de la investigaciones realizadas sobre incendios no mencionan la interaccion de incendio y herbivoros. Por lo que es dificil juzgar, la influencia del fuego dentro del contexto del herbivoro. Resultados de la presente investigación sugieren que la pradera se recupera mas rapidamente a Ia interaccion de fuego y herbivoro de lo que se creia inicialmente.

that prairie is far more resilient to burning in any season than is accepted commonly by conventional wisdom.

Prescribed fire for livestock management in the grasslands of Oklahoma and Kansas is usually intended to enhance forage quality for cattle. Fires conducted early in the freeze-free period of the spring, traditionally referred to as late spring, coincide with resumption of active growth of warm-season grasses following winter dormancy. Late spring burning has been recommended for optimum cattle production (Launchbaugh and Owensby 1978). Fires conducted in winter or early spring are intended to enhance wildlife habitat (Riggs et al. 1996) and avoid disrupting nesting of ground-nesting birds (Zimmerman 1997). Burning earlier than late spring may also ensure adequate time to fulfill all burning plans (Roberts et al. 1999). 
Wildfire may occur any time of the year provided dry, fine fuel is sufficient to carry the fire. Wildfire often disrupts management by consuming standing forage and damaging wood structures. But wildfire and even prescribed fire in seasons other than late spring also present the potential of reducing post-fire forage production and changing species composition. To this point, managers adjusting stocking rate or making other management decisions in the wake of wildfire or prescribed fire outside the traditional late spring burning period have but a few published recommendations on which to base their decisions (Launchbaugh and Owensby 1978, Ohlenbusch 1992). A comprehensive examination of the available literature and perhaps additional research are needed to support management decisions on timing prescribed burns and responding to wildfire. We reviewed the literature and revisited some original data sets to quantify the influence of season of burning on plant production and species composition in Oklahoma and Kansas native grasslands.

Voluminous research demonstrates that tallgrass prairie burned in the late spring starts growth earlier, grows more rapidly early in the growing season, and produces more tallgrasses than unburned prairie. However, we intend to contrast the effects of burning at seasons other than in late spring, even as early as late in the previous growing season, with burning late spring and with not burning.

We use published data to construct a perspective of how native grasslands in Oklahoma and Kansas respond to season of fire, and we focus our review of fire effects on herbage production and composition. By far, the majority of fire literature comes from the tallgrass prairie, but we present the available data on mixed prairie as well. To be consistent with most of the published literature, we divide our treatment into 2 broad seasons of fire based on the ratio of dead to live of warm-season grasses, which comprise the bulk of the fine fuel in these grasslands. First, the dormant season follows the first killing freeze of autumn when the first $0^{\circ} \mathrm{C}$ temperature dramatically increases the ratio of dead to live of fine fuels. The dormant season continues for several weeks into the freezefree period (i.e., late spring), which is after the final $0^{\circ} \mathrm{C}$ temperature of the winter when fine fuels still have a high ratio of dead to live but after warm-season grasses have commenced growth. Second, the growing season refers to the freeze-free period of the year when fine fuels have substantial amounts of live tissue above ground and therefore a low ratio of dead to live. However, fine fuels in the late growing season have greater ratios of dead to live than fine fuels in the early growing season. The greater ratio of dead to live combined with the warmer and drier weather conditions of late growing season favor fire spread and higher fire intensity (Bragg 1982). Except perhaps in severe drought, the dead-to-live ratio is less in the late growing season than in the dormant season.

\section{Tallgrass Prairie}

\section{Dormant-Season Fire}

Data from 2 studies in the northern Flint Hills near Manhattan, Kansas (Anderson et al. 1970, Towne and Owensby 1984) are often cited to support management decisions with regard to timing prescribed fire within the dormant season on tallgrass prairie. However, a considerable body of literature from other tallgrass prairie study sites in Kansas and Oklahoma expands the basis for judging the effects of dormantseason fire on herbage production and species composition (Tables 1 and 2).

Some of the first scientific reports of fire in tallgrass prairie were unreplicated observations following wildfire, included little if any information about the fire environment, and the comparison unburned area was subjectively selected (see Kelting 1957, Adams and Anderson 1978, Adams et al. 1982). An early study that impeded the acceptance of prescribed fire in Oklahoma reported that fire reduced plant production and resulted in soil erosion (Elwell et al. 1941), but the effects of fire were confounded by grazing and site differences. Other studies (Kelting 1957, Adams et al. 1982) did not include herbage production as a response measurement, complicating the application to rangeland management where herbivory by livestock or wildlife is important.

Few studies outside of those in the northern Flint Hills of Kansas examined the effect of burn date within the dormant season. In a study that included considerable variation in burning dates, burn date either had no influence, or later burn dates reduced herbage production and decreased production of forage grasses. In this study, Bidwell et al. (1990) investigated the influence of fire type (headfire vs. backfire) and burning (burn vs. no burn) on herbage production and composition at 2 clipping dates (June and August) in the first growing season after burning in each of 2 years (1986 and 1987). The study was conducted in a moderately grazed tallgrass prairie in northcentral Oklahoma. We subjected the original data to simple linear regression using date of burning (March 6 to April 23) as the independent variable and total herbage production and species groups as dependent variables. Total herbage production in June and August 1986 declined with later burning dates in the dormant season, but no significant linear relationship was detected for either harvest date in 1987 (Fig. 1). The effect of burn date on total herbage production was greatest in June 1986 when plots burned in early March produced nearly double that of plots burned in late April (Fig. 1, Table 1). Production of perennial grasses was greater in plots burned in early March than in plots burned in late April of 1986, but burning date had no influence on perennial grass production in 1987 (Tables 1 and 2). Similarly, production of tallgrasses, forbs, and legumes in 1986 declined generally with later burning dates.

In a synthesis of research from the northern Flint Hills of Kansas, Launchbaugh and Owensby (1978) stated that early dormant-season burning (i.e., at dates in the dormant season earlier than late spring) reduces plant production and increases forbs at the expense of desirable forages, especially the warm-season tallgrasses. This body of research indicates convincingly that burning earlier than late spring (about 1 May at this latitude) in grazed prairie reduces overall herbage production and favors forbs over perennial grasses compared to unburned prairie (McMurphy and Anderson 1963, 1965, Owensby and Anderson 1967, Anderson et al. 1970, Towne and Owensby 1984, Gibson 1989). Combined with a long-term study on ungrazed plots (Towne and Owensby 1984) (Tables 1 and 2), these data demonstrate that a late-spring burning date in the northern Flint Hills of Kansas optimizes production of desirable forage grasses relative to burning earlier in the dormant season. But, we argue that burning at dates earlier in the dormant season did not increase forbs or consistently decrease perennial forage grasses compared to the no-burn treatment. Conventional wisdom in the region holds that burning in the dormant-season other than in the late dormantseason (late spring) always reduces herbage production and increases weedy forbs relative to desirable forage grasses.

Vegetation response to fire in tallgrass prairie varies with factors other than burning date. The response varies with fire history (fire frequency and fire-return interval) (Gibson and Hulbert 1987, Blair 
Table 1. Response of herbage production to fire in different times of the dormant season in tallgrass prairies. Measurements were the growing season after fire unless otherwise indicated. Comparison is with unburned check unless otherwise indicated.

\begin{tabular}{|c|c|c|c|c|c|c|c|}
\hline \multirow[b]{2}{*}{ Timing of fire } & \multirow[b]{2}{*}{ Location } & \multirow[b]{2}{*}{$\begin{array}{l}\text { Seral } \\
\text { stage }\end{array}$} & \multicolumn{3}{|c|}{$\begin{array}{l}\text { Change as a percent (and change in biomass, } \\
\mathrm{kg} / \mathrm{ha} \text { ) as a result of fire } \\
\end{array}$} & \multirow[b]{2}{*}{ Comments } & \multirow[b]{2}{*}{ Reference } \\
\hline & & & $\begin{array}{l}\text { Perennial } \\
\text { grass }\end{array}$ & Forb + legume & $\begin{array}{c}\text { Total } \\
\text { production }\end{array}$ & & \\
\hline$\overline{\text { Fall }}$ & $\begin{array}{l}\text { Central } \\
\text { Oklahoma }\end{array}$ & Mid to late & Not reported & Not reported & $\begin{array}{c}-53 \text { to }-59 \% \\
(-1,520 \text { to }-720)\end{array}$ & $\begin{array}{l}\text { Ungrazed abandoned } \\
\text { cropland and grazed } \\
\text { prairie burned annually } \\
\text { for } 8 \text { years. Exact burn } \\
\text { dates not reported } \\
\text { Sampled at end of } \\
8 \text { years of burning }\end{array}$ & $\begin{array}{l}\text { Elwell et al. } \\
(1941)\end{array}$ \\
\hline November & $\begin{array}{l}\text { Central } \\
\text { Oklahoma }\end{array}$ & $\begin{array}{l}\text { Mid to } \\
\text { late }\end{array}$ & Not reported & $+58 \%(140)$ & $+64 \%(840)$ & $\begin{array}{l}\text { Wildfire on area not } \\
\text { grazed or mowed in } \\
\text { previous years. } \\
\text { Dominated by little } \\
\text { bluestem. Dry year } \\
\text { following the fire. } \\
\text { Peak green } \\
\text { biomass reported } \\
\text { for total production. }\end{array}$ & $\begin{array}{l}\text { Adams and } \\
\text { Anderson } \\
(1978)\end{array}$ \\
\hline $\begin{array}{l}\text { Early March to } \\
\text { late April. } \\
\text { Measured in } \\
\text { June }\end{array}$ & $\begin{array}{l}\text { Northcentral } \\
\text { Oklahoma }\end{array}$ & Late & $\begin{array}{c}1986 \text { burns } \\
+74 \% \\
(+25 / \text { day }) \\
1987 \text { burns } \\
\text { nc }^{1}\end{array}$ & $\begin{array}{c}1986 \text { burns } \\
+146 \% \\
(+6 / \text { day }) \\
1987 \text { burns } \\
\text { nc }\end{array}$ & $\begin{array}{c}1986 \text { burns } \\
+94 \% \\
(+36 / \text { day }) \\
1987 \text { burns } \\
\text { nc }^{1}\end{array}$ & $\begin{array}{l}\text { Fires (in } 1986 \text { and } \\
\text { 1987) followed } \\
\text { moderate grazing. } \\
\text { Responses } \\
\text { averaged over fire } \\
\text { type. Comparison } \\
\text { with late April burn. }\end{array}$ & $\begin{array}{l}\text { Bidwell et al. } \\
\text { (1990) }\end{array}$ \\
\hline $\begin{array}{l}\text { Early March to } \\
\text { late April } \\
\text { Measured in } \\
\text { August }\end{array}$ & $\begin{array}{l}\text { Northcentral } \\
\text { Oklahoma }\end{array}$ & Late & $\begin{array}{c}1986 \text { burns } \\
+17 \% \\
(+16 / \text { day }) \\
1987 \text { burns } \\
\text { nc }\end{array}$ & $\begin{array}{c}1986 \text { burns } \\
\text { nc } \\
1987 \text { burns } \\
\text { nc }^{1}\end{array}$ & $\begin{array}{c}1986 \text { burns } \\
+21 \% \\
(+21 / \text { day }) \\
1987 \text { burns } \\
\text { nc }^{1}\end{array}$ & $\begin{array}{l}\text { Fires (in } 1986 \text { and } \\
\text { 1987) followed } \\
\text { moderate grazing. } \\
\text { Responses } \\
\text { averaged over fire } \\
\text { type. Comparison } \\
\text { with late April burn. }\end{array}$ & $\begin{array}{l}\text { Bidwell et al. } \\
\text { (1990) }\end{array}$ \\
\hline $\begin{array}{l}\text { November, } \\
\text { February and } \\
\text { April }\end{array}$ & $\begin{array}{l}\text { Northcentral } \\
\text { Oklahoma }\end{array}$ & Mid & $\mathrm{nc}$ & $\begin{array}{c}\text { Nov. burn } \\
\text { nc to } \\
+126 \% \\
\text { (nc to }+290 \text { ) } \\
\text { in year } 2 \text { of } \\
\text { one study } \\
\text { Feb. burn } \\
\text { nc } \\
\text { Apr. burn } \\
\text { nc }\end{array}$ & $\begin{array}{c}\text { Year } 1 \\
\text { Nov. burn } \\
\text { nc to }-33 \% \\
\text { (nc to }-870) \\
\text { Feb. burn } \\
\text { nc to }-25 \% \\
\text { (nc to }-670) \\
\text { Apr. burn } \\
\text { nc to }-42 \% \\
\text { (nc to }+2050)\end{array}$ & $\begin{array}{l}\text { Decrease in total } \\
\text { production } \\
\text { concomitant with } \\
\text { threeawn reduction. }\end{array}$ & $\begin{array}{l}\text { Engle et al. } \\
\text { (1990) }\end{array}$ \\
\hline $\begin{array}{l}\text { Winter to late } \\
\text { spring }\end{array}$ & $\begin{array}{l}\text { Northern } \\
\text { Kansas } \\
\text { Flint Hills }\end{array}$ & Late & $\begin{array}{l}\text { Dec. burn } \\
+14 \%(500) \\
\text { Mar. burn } \\
+11 \%(400) \\
\text { Apr. burn } \\
+22 \%(800) \\
\text { May burn } \\
+36 \%(1300)\end{array}$ & $\begin{array}{l}\text { Dec. burn } \\
-38 \%(300) \\
\text { Mar. burn } \\
-38 \%(300) \\
\text { Apr. burn } \\
-38 \%(300) \\
\text { May burn } \\
-75 \%(600)\end{array}$ & $\begin{array}{l}\text { Dec. burn } \\
\text { nc } \\
\text { Mar. burn } \\
\text { nc } \\
\text { Apr. burn } \\
+14 \%(600) \\
\text { May burn } \\
+16 \%(700)\end{array}$ & $\begin{array}{l}\text { Ungrazed plots } \\
\text { annually burned } \\
\text { 1928-1982. } \\
\text { Production data } \\
\text { average of 1973- } \\
\text { 1982. Perennial } \\
\text { grasses column } \\
\text { includes all grasses. }\end{array}$ & $\begin{array}{l}\text { Towne and } \\
\text { Owensby } \\
(1984)\end{array}$ \\
\hline $\begin{array}{l}\text { Early spring to } \\
\text { late spring }\end{array}$ & $\begin{array}{l}\text { Northern } \\
\text { Kansas } \\
\text { Flint Hills }\end{array}$ & Late & $\begin{array}{l}\text { Mar. burn } \\
-33 \%(1310) \\
\text { Apr. burn } \\
-18 \%(690) \\
\text { May burn } \\
\text { nc }^{2}\end{array}$ & $\begin{array}{l}\text { Mar. burn } \\
\text { nc } \\
\text { Apr. burn } \\
\text { nc } \\
\text { May burn } \\
-47 \%(140)\end{array}$ & Not reported & $\begin{array}{l}\text { Grazed pastures } \\
\text { burned annually } \\
1950-1966 \text {. Data } \\
\text { from uplands. } \\
\text { Forage (non weedy) } \\
\text { reported for perennial } \\
\text { grasses and weeds for } \\
\text { forbs+legumes. }\end{array}$ & $\begin{array}{l}\text { Anderson } \\
\text { et al. (1970) }\end{array}$ \\
\hline $\begin{array}{l}\text { Mid November } \\
\text { to late April }\end{array}$ & $\begin{array}{l}\text { Northern } \\
\text { Kansas } \\
\text { Flint Hills }\end{array}$ & Late & Not reported & Not reported & $\begin{array}{l}\text { After } 1 \text { year } \\
\text { Mid Nov. } \\
+26 \%(620) \\
\text { Late Apr. } \\
+29 \%(680) \\
\\
\text { After } 2 \text { years } \\
\text { Mid Nov. } \\
+68 \%(3270) \\
\text { Mid Apr. } \\
+76 \%(3660)\end{array}$ & $\begin{array}{l}\text { Burned two } \\
\text { consecutive years. } \\
\text { Data averaged over } \\
\text { irrigated and rain- } \\
\text { fed because } \\
\text { irrigation had no } \\
\text { effect. Plots not } \\
\text { grazed. }\end{array}$ & James (1985) \\
\hline
\end{tabular}

\footnotetext{
${ }_{n c}=$ no change $(P>0.05)$ was detected, i.e., by analysis of the slope coefficient in regression analysis, from early March to late April burning.
}

${ }^{2} \mathrm{nc}=$ no difference $(\mathrm{P}>0.05)$ as compared to unburned checks or late spring burning. 
Table 2. Change in composition of herbage in tallgrass prairie in response to fire in different times of the dormant season other than late spring in tallgrass prairies of the central Great Plains. Measurements were the growing season after fire unless otherwise indicated.

\begin{tabular}{|c|c|c|c|c|c|c|c|c|c|c|}
\hline \multirow[b]{2}{*}{$\begin{array}{l}\text { Timing of } \\
\text { fire }\end{array}$} & \multirow[b]{2}{*}{ Location } & \multirow[b]{2}{*}{$\begin{array}{l}\text { Seral } \\
\text { stage }\end{array}$} & \multicolumn{6}{|c|}{$\begin{array}{c}\text { Change }^{1} \text { in relative composition following burning as compared } \\
\text { to late spring burn or check }\end{array}$} & \multirow[b]{2}{*}{ Comments } & \multirow[b]{2}{*}{ Reference } \\
\hline & & & Tallgrass & $\begin{array}{l}\text { Perennial } \\
\text { grass }\end{array}$ & $\begin{array}{l}\text { Little } \\
\text { bluestem }\end{array}$ & $\begin{array}{l}\text { Forb+ } \\
\text { legume }\end{array}$ & Forb & Legume & & \\
\hline November & $\begin{array}{l}\text { Central } \\
\text { Oklahoma }\end{array}$ & $\begin{array}{l}\text { Mid to } \\
\text { late }\end{array}$ & $\begin{array}{c}\text { Not } \\
\text { reported }\end{array}$ & $\begin{array}{c}\text { Not } \\
\text { reported }\end{array}$ & $\begin{array}{c}\text { Not } \\
\text { reported }\end{array}$ & $\begin{array}{c}\text { Not } \\
\text { reported }\end{array}$ & + & + & $\begin{array}{l}\text { Wildfire on area } \\
\text { not grazed or } \\
\text { mowed in previous } \\
\text { years. Dominated by } \\
\text { little bluestem } \\
\text { Dry year following } \\
\text { the fire. Peak green } \\
\text { biomass reported for } \\
\text { total production. }\end{array}$ & $\begin{array}{l}\text { Adams and } \\
\text { Anderson } \\
(1978)\end{array}$ \\
\hline February & $\begin{array}{l}\text { Central } \\
\text { Oklahoma }\end{array}$ & Late & + & + & + & - & $\mathrm{nr}$ & $\mathrm{nr}$ & $\begin{array}{l}\text { Area not grazed for } \\
2 \text { years before fire. } \\
\text { Big bluestem-reduced } \\
\text { by fire, but other } \\
\text { tallgrasses increased. }\end{array}$ & $\begin{array}{l}\text { Ketling } \\
(1957)\end{array}$ \\
\hline March & $\begin{array}{l}\text { South- } \\
\text { central } \\
\text { Oklahoma }\end{array}$ & $\begin{array}{l}\text { Mid to } \\
\text { late }\end{array}$ & - & - & - & + & $\mathrm{nc}$ & + & $\begin{array}{l}\text { Abandoned cropland } \\
\text { naturally revegetated } \\
\text { with tallgrasses and } \\
\text { woody species. } \\
\text { Comparison is pre- } \\
\text { and post-burn. }\end{array}$ & $\begin{array}{l}\text { Adams et al. } \\
(1982)\end{array}$ \\
\hline $\begin{array}{l}\text { Early March. } \\
\text { Measured in } \\
\text { June }\end{array}$ & $\begin{array}{l}\text { North- } \\
\text { central } \\
\text { Oklahoma }\end{array}$ & Late & $\begin{array}{l}+(1986) \\
\text { nc }(1987)\end{array}$ & $\begin{array}{l}+(1986) \\
\text { nc }(1987)\end{array}$ & $\begin{array}{l}+(1986) \\
\text { nc }(1987)\end{array}$ & $\begin{array}{c}+(1986) \\
\text { nc }(1987)\end{array}$ & $\begin{array}{c}+(1986) \\
\text { nc }(1987)\end{array}$ & $\begin{array}{l}\text { nc }(1986) \\
\text { nc }(1987)\end{array}$ & $\begin{array}{l}\text { Burned (in } 1986 \text { and } \\
\text { and 1987) following } \\
\text { moderate grazing. } \\
\text { Responses averaged } \\
\text { over fire type. } \\
\text { Comparison with late } \\
\text { April burn. }\end{array}$ & $\begin{array}{l}\text { Bidwell et } \\
\text { al. (1990) }\end{array}$ \\
\hline $\begin{array}{l}\text { Early March. } \\
\text { Measured } \\
\text { in August }\end{array}$ & $\begin{array}{l}\text { North- } \\
\text { central } \\
\text { Oklahoma }\end{array}$ & Late & $\begin{array}{l}\text { nc }(1986) \\
\text { nc }(1987)\end{array}$ & $\begin{array}{l}+(1986) \\
\text { nc (1987) }\end{array}$ & $\begin{array}{l}\text { nc }(1986) \\
\text { nc }(1987)\end{array}$ & $\begin{array}{l}\text { nc }(1986) \\
\text { nc }(1987)\end{array}$ & $\begin{array}{l}\text { nc (1986) } \\
\text { nc (1987) }\end{array}$ & $\begin{array}{l}\text { nc (1986) } \\
-(1987)\end{array}$ & $\begin{array}{l}\text { Burned in } 1986 \text { and } \\
\text { 1987) following } \\
\text { moderate grazing } \\
\text { Responses averaged } \\
\text { over fire type. } \\
\text { Comparison with } \\
\text { late April burn. }\end{array}$ & $\begin{array}{l}\text { Bidwell et } \\
\text { al. (1990) }\end{array}$ \\
\hline $\begin{array}{l}\text { November, } \\
\text { February, } \\
\text { and April }\end{array}$ & $\begin{array}{l}\text { North- } \\
\text { central } \\
\text { Oklahoma }\end{array}$ & Mid & $\mathrm{nc}$ & $\mathrm{nc}$ & nc & $\begin{array}{l}\text { nc to }+ \text { in } \\
\text { year } 2 \text { of } \\
\text { Nov. }\end{array}$ & $\begin{array}{l}\text { Not } \\
\text { reported }\end{array}$ & $\begin{array}{l}\text { Not } \\
\text { reported }\end{array}$ & $\begin{array}{l}\text { Production of } \\
\text { desirable hay } \\
\text { species, mostly } \\
\text { perennial grasses, } \\
\text { increased by burns } \\
\text { that reduced prairie } \\
\text { threeawn. Compared } \\
\text { to no burn. }\end{array}$ & $\begin{array}{l}\text { Engle et al. } \\
\text { (1990) }\end{array}$ \\
\hline $\begin{array}{l}\text { November } \\
\text { to March }\end{array}$ & $\begin{array}{l}\text { Central and } \\
\text { Eastern } \\
\text { Kansas }\end{array}$ & Mid & $\begin{array}{c}\text { Not } \\
\text { reported }\end{array}$ & + & $\begin{array}{l}\text { Not } \\
\text { reported }\end{array}$ & Not reported & + & $\begin{array}{l}\text { Not } \\
\text { reported }\end{array}$ & $\begin{array}{l}\text { December burn } \\
\text { controlled prairie } \\
\text { threeawn and released } \\
\text { forbs and perennial } \\
\text { grasses. Compared } \\
\text { to no burn. }\end{array}$ & $\begin{array}{l}\text { Owensby } \\
\text { and } \\
\text { Launch- } \\
\text { baugh } \\
(1977)\end{array}$ \\
\hline $\begin{array}{l}\text { Winter to } \\
\text { late spring } \\
\text { compared } \\
\text { to no burn }\end{array}$ & $\begin{array}{l}\text { Northern } \\
\text { Kansas } \\
\text { Flint Hills }\end{array}$ & Late & + & + & $\begin{array}{l}\text { - Dec. and } \\
\text { May } \\
\text { + Mar. and } \\
\text { Apr. }\end{array}$ & $\begin{array}{l}\text { nc Dec. } \\
\text { + Mar. } \\
\text {-Apr. } \\
\text {-May }\end{array}$ & $\begin{array}{l}\text { Not } \\
\text { reported }\end{array}$ & $\begin{array}{l}\text { Not } \\
\text { reported }\end{array}$ & $\begin{array}{l}\text { Big bluestem basal } \\
\text { cover reported for } \\
\text { tallgrasses and } \\
\text { perennial forbs } \\
\text { basal cover reported } \\
\text { for forbs+legumes. } \\
\text { Little bluestem basal } \\
\text { cover. }\end{array}$ & $\begin{array}{l}\text { Towne and } \\
\text { Owensby } \\
(1984)\end{array}$ \\
\hline $\begin{array}{l}\text { Early spring } \\
\text { to late spring } \\
\text { compared to } \\
\text { no burn }\end{array}$ & $\begin{array}{l}\text { Northern } \\
\text { Kansas } \\
\text { Flint Hills }\end{array}$ & Late & $\begin{array}{l}\text { +all burn } \\
\text { dates }\end{array}$ & $\begin{array}{l}\text { Not } \\
\text { reported }\end{array}$ & $\begin{array}{c}\text {-Mar. } \\
\text { nc Apr. and } \\
\text { May }\end{array}$ & $\begin{array}{l}\text { +Mar. } \\
\text {-Apr. } \\
\text {-May }\end{array}$ & $\begin{array}{l}\text { Not } \\
\text { reported }\end{array}$ & $\begin{array}{l}\text { Not } \\
\text { reported }\end{array}$ & $\begin{array}{l}\text { Grazed pastures } \\
\text { burned annually } \\
\text { 1950-1966. Big } \\
\text { bluestem reported for } \\
\text { tallgrasses. Perennial } \\
\text { forbs reported for forbs } \\
\text { + legumes. Data } \\
\text { are canopy cover. }\end{array}$ & $\begin{array}{l}\text { Anderson } \\
\text { et al. (1970) }\end{array}$ \\
\hline $\begin{array}{l}\text { November, } \\
\text { March, and } \\
\text { late April } \\
\text { compared } \\
\text { to no burn }\end{array}$ & $\begin{array}{l}\text { Northern } \\
\text { Kansas } \\
\text { Flint Hills }\end{array}$ & Late & $\begin{array}{l}\text { +all burn } \\
\text { dates }\end{array}$ & - to+ & $\begin{array}{l}\text { +all burn } \\
\text { dates }\end{array}$ & $\begin{array}{l}\text { +Nov. } \\
\text { +Mar. } \\
\text {-Apr. }\end{array}$ & $\begin{array}{l}\text { Not } \\
\text { reported }\end{array}$ & $\begin{array}{l}\text { Not } \\
\text { reported }\end{array}$ & $\begin{array}{l}\text { Areas burned } \\
\text { annually but not } \\
\text { grazed. Data are } \\
\text { canopy cover }\end{array}$ & $\begin{array}{l}\text { Gibson } \\
\text { (1989) }\end{array}$ \\
\hline
\end{tabular}

$+=$ increase, $-=$ decrease, $n c=$ no difference $(\mathrm{P}>0.05)$ as compared to unburned checks or late spring burning. 

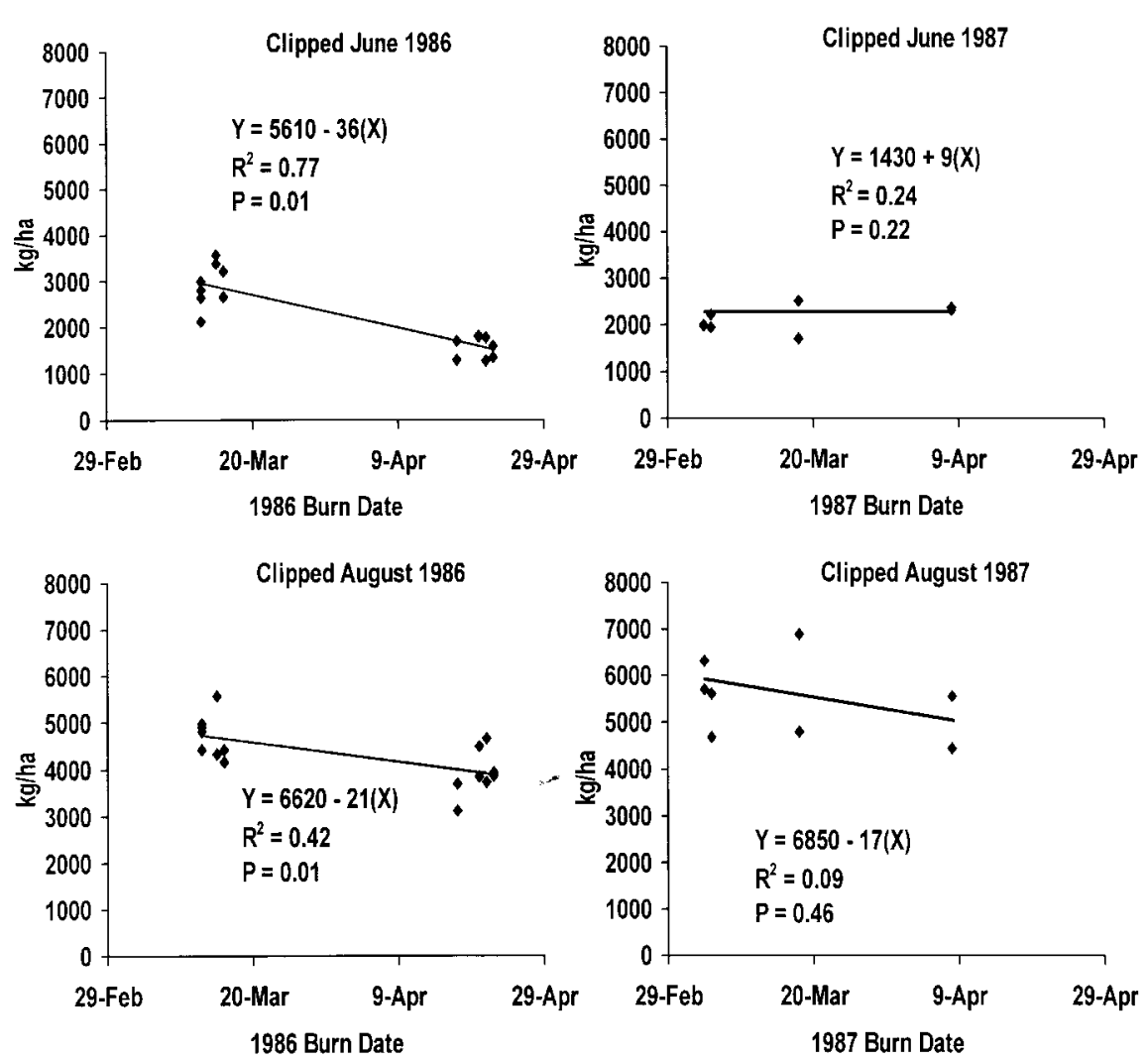

Fig. 1. Total herbage produced following dormant-season fires in moderately grazed tallgrass prairie in northcentral Oklahoma as measured on 2 dates in the first growing season. The independent variable is Julian date. Calendar dates are presented on the $\mathrm{x}$-axes to aid interpretation. The slope coefficients of the equations for 1987 were not significant $(P>$ 0.05).

1997, Engle et al. 1998), grazing history (Ewing and Engle 1988, Collins et al. 1998), and possibly with differences in herbicide use. Soil texture and topographic position also have a pronounced influence on response (Anderson et al. 1970, Abrams et al. 1986, Briggs and Knapp 1995) and may explain some of the apparent discrepancies among studies. For example, soil-water properties in the Flint Hills with soils derived from chert differ from soils derived from shale in northcentral Oklahoma. The greater water-holding capacity of Oklahoma soils coupled with an increase in soil temperature after burning that effectively prolongs the length of the early growing season (Hulbert 1969, 1988, Rice and Parenti 1978) could explain enhanced production with earlier burning in the study by Bidwell et al. (1990) compared to the Flint Hills studies. Herbage production often is higher on burned areas than areas not burned in the more humid prairie peninsula where excessive mulch accumulations depress production (Old 1969, Kucera and Ehrenreich 1962). Herbage production may also increase following late spring burning in Oklahoma and Kansas tallgrass prairies in which excessive mulch accumulates in the absence of burning or heavy grazing or where the fire-altered microclimate does not negatively influence growing conditions (Graves and McMurphy 1969, Anderson et al. 1970, Powell et al. 1979, Towne and Owensby 1984, James 1985, Bidwell et al. 1990).

Successional stage may also override the influence of season of fire on vegetation. For example, early dormant-season fire (November-February) reduces prairie threeawn (Aristida oligantha Michx.) on areas heavily infested with this unpalatable annual grass by reducing mulch levels and combusting the seed (Owensby and Launchbaugh 1977, Engle et al. 1990). Late-spring burning (April), especially when repeated annually for several years, also may reduce prairie threeawn (Graves and McMurphy 1969, Engle et al. 1990) and truncate the decades of dominance by prairie threeawn possible in the absence of fire (Rice 1971, Engle et al. 1990). The resulting increase in desirable forage species for cattle is generally less than the loss of prairie threeawn, so total herbage production decreases the year after burning (Tables 1 and 2) (Owensby and
Launchbaugh 1977, Engle et al. 1990).

Burning early in the dormant season may have livestock management benefits. Burning increases the length of the growing season by warming the soil in spring (Hulbert 1988) and increasing photosynthetically active radiation (Knapp 1984), which can speed the production of herbage early in the growing season (Smith and Owensby 1972, Adams and Anderson 1978, Knapp 1984, Mitchell et al. 1996). Although burning earlier than late spring may kill some cool-season annuals and biennial forbs (Kelting 1957, Towne and Knapp 1996), it can also stimulate production of some cool-species species, including sedges (Mitchell et al. 1996), that can provide a high-quality forage important to wildlife and livestock (Coppedge et al. 1998b). Moreover, even though early burning may sometimes increase forbs, the increase is relatively small and does not appear to come at the expense of perennial grasses when compared to areas not burned (Tables 1 and 2).

\section{Late Growing-Season Fire}

The comparatively meager research on late growing-season fire in tallgrass prairie is ironic considering the frequency of growing-season fire in both prehistoric and contemporary times. Because of the often hot dry conditions under which fire in this season occurs, one might assume a fire in the late growing season would lead to long-term changes in species composition and reduced herbage production. The limited research literature suggests the opposite.

Ewing and Engle (1988) investigated the influence of late-summer fire in 2 northcentral Oklahoma tallgrass prairies, one with a history of no grazing and the other a history of moderate grazing by cattle (Tables 3 and 4). As is common in tallgrass prairie (Hulbert 1969, Hulbert 1988), the ungrazed prairie had a substantial accumulation of mulch and litter, which supported an intense fire relative to the grazed prairie. Carry-over effects of fires to a second year after the burns were reported by Engle et al. (1992). This study emphasizes the role of grazing history in how vegetation responds to fire, and it supports the results of Bidwell et al. (1990) that timing of measurement of fire effects also influences how the effects of fire might be interpreted. It also indicates that late growing-season fire leads to neither large nor long-term changes in production and species composition.

Adams et al. (1982) compared pre-fire and post-fire responses to a mid-July fire 
Table 3. Response of herbage production to fire in different times in the growing season on tallgrass prairies. Measurements were the growing season after fire.

\begin{tabular}{|c|c|c|c|c|c|c|c|}
\hline \multirow[b]{2}{*}{ Timing of fire } & \multirow[b]{2}{*}{ Location } & \multicolumn{4}{|c|}{$\begin{array}{l}\text { Change as a percent (and change in biomass } \\
\mathrm{kg} / \mathrm{ha} \text { ) as a result of fire }\end{array}$} & \multirow[b]{2}{*}{ Comments } & \multirow[b]{2}{*}{ Reference } \\
\hline & & $\begin{array}{l}\text { Seral } \\
\text { stage }\end{array}$ & $\begin{array}{l}\text { Perennial } \\
\text { grass }\end{array}$ & Forb + legume & $\begin{array}{c}\text { Total } \\
\text { production }\end{array}$ & & \\
\hline $\begin{array}{l}\text { Late summer } \\
\text { (September 5) } \\
\text { Measured in } \\
\text { June }\end{array}$ & $\begin{array}{l}\text { Northcentral } \\
\text { Oklahoma }\end{array}$ & Mid & $\begin{array}{c}\text { Year } 1 \\
-41 \%(-960) \\
\text { Year } 2 \\
\text { nc }^{1}\end{array}$ & $\begin{array}{c}\text { Year } 1 \\
-112 \%(-260) \\
\text { Year } 2 \\
+171 \%(+294)\end{array}$ & $\begin{array}{c}\text { Year } 1 \\
\text { nc } \\
\text { Year } 2 \\
\text { nc }\end{array}$ & $\begin{array}{l}\text { Burned in } 1985 . \\
\text { Moderately grazed. } \\
4,400 \mathrm{~kg} / \text { ha fuel. }\end{array}$ & $\begin{array}{l}\text { Ewing and } \\
\text { Engle } \\
(1988), \\
\text { Engle et al. } \\
(1992)\end{array}$ \\
\hline $\begin{array}{l}\text { Late summer } \\
\text { (September 5) } \\
\text { Measured in } \\
\text { June }\end{array}$ & $\begin{array}{l}\text { Northcentral } \\
\text { Oklahoma }\end{array}$ & Late & $\begin{array}{c}\text { Year } 1 \\
-27 \% \\
-540 \mathrm{~kg} / \mathrm{ha} \\
\text { Year } 2 \\
\text { nc }\end{array}$ & $\begin{array}{c}\text { Year } 1 \\
+173 \% \\
+1,610 \mathrm{~kg} / \mathrm{ha} \\
\text { Year } 2 \\
\text { nc }\end{array}$ & $\begin{array}{l}\text { Year } 1 \\
\text { nc } \\
\text { Year } 2 \\
\text { nc }\end{array}$ & $\begin{array}{l}\text { Burned in } 1985 . \\
\text { Ungrazed. } \\
10,300 \mathrm{~kg} / \text { ha fuel. }\end{array}$ & $\begin{array}{l}\text { Ewing and } \\
\text { Engle } \\
(1988) . \\
\text { Engle et al. } \\
\text { (1992) }\end{array}$ \\
\hline $\begin{array}{l}\text { Late summer } \\
\text { (September 5) } \\
\text { Measured in } \\
\text { August }\end{array}$ & $\begin{array}{l}\text { Northcentral } \\
\text { Oklahoma }\end{array}$ & Mid & $\begin{array}{c}\text { Year } 1 \\
\text { nc }\end{array}$ & & $\begin{array}{c}\text { Year } 1 \\
\text { nc }\end{array}$ & $\begin{array}{l}\text { Burned in } 1985 . \\
\text { Moderately grazed. } \\
4,400 \mathrm{~kg} / \text { ha fuel. }\end{array}$ & $\begin{array}{l}\text { Ewing and } \\
\text { Engle } \\
\text { (1988). } \\
\text { Engle et al. } \\
\text { (1992) }\end{array}$ \\
\hline $\begin{array}{l}\text { Late Summer } \\
\text { (September 5) } \\
\text { Measured in } \\
\text { August }\end{array}$ & $\begin{array}{l}\text { Northcentral } \\
\text { Oklahoma }\end{array}$ & Late & $\begin{array}{c}\text { Year } 1 \\
\text { nc }\end{array}$ & $\begin{array}{c}\text { Year } 1 \\
\text { nc }\end{array}$ & $\begin{array}{c}\text { Year } 1 \\
\text { nc }\end{array}$ & $\begin{array}{l}\text { Burned in } 1985 . \\
\text { Ungrazed. } \\
10,300 \mathrm{~kg} / \text { ha fuel. }\end{array}$ & $\begin{array}{l}\text { Ewing and } \\
\text { Engle } \\
(1988), \\
\text { Engle et al. } \\
(1992)\end{array}$ \\
\hline $\begin{array}{l}\text { Late summer } \\
\text { (September) }\end{array}$ & $\begin{array}{l}\text { Northcentral } \\
\text { Oklahoma }\end{array}$ & Late & $\begin{array}{c}\text { Year } 1 \\
-39 \%(-1,200) \\
\text { Year } 2 \\
\text { nc }\end{array}$ & $\mathrm{nc}$ & $\begin{array}{c}\text { Year } 1 \\
-16 \%(-580) \\
\text { Year } 2 \\
\text { nc }\end{array}$ & $\begin{array}{l}\text { Burned in } 1988 \text { and } \\
1989 . \text { Plots burned in } \\
\text { moderately grazed } \\
\text { pasture. } 8,200 \mathrm{~kg} / \mathrm{ha} \text { fuel } \\
\text { Forb production was } \\
\text { highly variable among } \\
\text { treatment plots. }\end{array}$ & $\begin{array}{l}\text { Engle et al. } \\
\text { (1993) }\end{array}$ \\
\hline $\begin{array}{l}\text { Late summer } \\
\text { to early fall } \\
\text { (Early August } \\
\text { to early } \\
\text { October) }\end{array}$ & $\begin{array}{l}\text { Southcentral } \\
\text { Oklahoma }\end{array}$ & Mid & $\begin{array}{c}\text { Loamy } \\
-54 \%(-1,280) \\
\text { Shallow } \\
\text { nc }\end{array}$ & $+53 \%(+690)$ & $\mathrm{nc}$ & $\begin{array}{l}\text { Burned } 2 \text { sites (shallow } \\
\text { and loamy) up to } 3 \text { times } \\
\text { in } 5 \text { years. Not grazed } \\
\text { the year of the first burn } \\
\text { and after for the duration } \\
\text { of the study. Prairie threeawn } \\
\text { abundant at the time of } \\
\text { the first burn. Response } \\
\text { reported for first burn only. }\end{array}$ & $\begin{array}{l}\text { Engle et al. } \\
\text { (1998) } \\
\text { in }\end{array}$ \\
\hline
\end{tabular}

${ }_{\mathrm{nc}}=$ no change $(\mathrm{P}>0.05)$ was detected as compared to unburned checks.

in an abandoned cropland naturally revegetated to tallgrass prairie (Table 4). Canopy cover of all grasses except switchgrass (Panicum virgatum L.) decreased the year after the fire in the burned area. Legumes increased and forbs decreased. Herbaceous vegetation was green, humidity was high, and wind speed low during this fire, suggesting a low intensity fire.

Engle et al. (1993) conducted the first replicated study on growing-season fires in grazed tallgrass prairie. Fire in this northcentral Oklahoma tallgrass prairie reduced herbage production for 1 year after the fire, but forb production was highly variable among plots and no statistically significant change in forbs was detected. Tallgrasses tolerated these September fires, but little bluestem (Schizachyrium scoparium (Michx.) Nash) was reduced for at least 2 years after fire. Little bluestem, a bunch grass, also decreased after burning on the ungrazed burn area in the study reported by Ewing and Engle (1988).

A study in mid-seral tallgrass prairie in southcentral Oklahoma suggests that tallgrass prairie is resilient to fire in the late growing season (Engle et al.1998). Tallgrasses and little bluestem, which were minor components of the vegetation, were reduced by 1 fire as were perennial grasses as a group on the more productive loamy site (Tables 3 and 4). The less productive, shallower site responded with fewer shifts in vegetation and no reduction in total production. The response after as many as 3 burns over 5 years indicates that late growing-season fire is an ephemeral, short-lived influence on plant production and species composition (Engle et al. 1998, 2000).

\section{Mixed Prairie}

The mixed prairie by definition is more arid than tallgrass prairie and fire in any season should dry the site further and reduce production. Although the research literature is not as rich as for the tallgrass prairies where fire is used more routinely in range management, sufficient research exists to indicate a variable response to fire in mixed prairie.

Early to mid dormant-season wildfires reduced grass production in western Kansas (Launchbaugh 1964, 1969, 1978 as cited in Owensby, unpublished). In contrast, a prescribed fire in late spring, timed to coincide with growth of dominant grasses, increased grass and total herbage yield (Launchbaugh 1978 as cited in Owensby, unpublished). Late spring burning 3 consecutive years resulted in variable changes in species composition and production (Launchbaugh 1978 as cited in 
Table 4. Change in composition of herbage in tallgrass prairie in response to fire in different times of the growing season in tallgrass prairies. Comparison is with unburned check unless indicated otherwise. Measurements were the growing season after fire.

\begin{tabular}{|c|c|c|c|c|c|c|c|c|c|c|}
\hline \multirow[b]{2}{*}{$\begin{array}{l}\text { Timing of } \\
\text { fire }\end{array}$} & \multirow[b]{2}{*}{ Location } & \multirow[b]{2}{*}{$\begin{array}{l}\text { Seral } \\
\text { stage }\end{array}$} & \multicolumn{6}{|c|}{ Change $^{1}$ in relative composition following burning } & \multirow[b]{2}{*}{ Comments } & \multirow[b]{2}{*}{ Reference } \\
\hline & & & Tallgrass & $\begin{array}{l}\text { Perennial } \\
\text { grass - }\end{array}$ & $\begin{array}{c}\text { Little } \\
\text { bluestem }\end{array}$ & $\begin{array}{l}\text { Forbs+ } \\
\text { legume }\end{array}$ & Forb & Legume & & \\
\hline July 14 & $\begin{array}{l}\text { South- } \\
\text { central } \\
\text { Oklahoma }\end{array}$ & $\begin{array}{l}\text { Mid to } \\
\text { late }\end{array}$ & + & $\begin{array}{c}\text { Not } \\
\text { reported }\end{array}$ & - & - & $\overline{-}$ & + & $\begin{array}{l}\text { Abandoned crop- } \\
\text { land naturally } \\
\text { revegetated with } \\
\text { tallgrasses and woody } \\
\text { species. Comparison is } \\
\text { pre- and post-burn. }\end{array}$ & $\begin{array}{l}\text { Adams et } \\
\text { et al. }\end{array}$ \\
\hline
\end{tabular}

\begin{tabular}{|c|c|c|c|c|c|c|c|c|c|c|}
\hline $\begin{array}{l}\text { Late summer } \\
\text { (September 5) } \\
\text { Measured in } \\
\text { June }\end{array}$ & $\begin{array}{l}\text { North- } \\
\text { central } \\
\text { Oklahoma }\end{array}$ & Mid & $\begin{array}{l}\text { nc (year 1) } \\
\text { nc (year 2) }\end{array}$ & $\begin{array}{c}-(\text { year } 1) \\
\text { nc (year 2) }\end{array}$ & $\begin{array}{l}\text { nc (year 1) } \\
\text { nc (year 2) }\end{array}$ & $\begin{array}{c}-(\text { year } 1) \\
\text { nc }(\text { year } 2)\end{array}$ & $\begin{array}{l}-(\text { year } 1) \\
+(\text { year } 2)\end{array}$ & $\begin{array}{l}\text { nc (year 1) } \\
\text { nc (year 2) }\end{array}$ & $\begin{array}{l}\text { Burned in } 1985 . \\
\text { Moderately grazed } \\
4,400 \mathrm{~kg} / \text { ha fuel. }\end{array}$ & $\begin{array}{l}\text { Ewing and } \\
\text { Engle } \\
(1988) . \\
\text { Engle et al. } \\
(1992)\end{array}$ \\
\hline $\begin{array}{l}\text { Late summer } \\
\text { (September } 5) \\
\text { Measured in } \\
\text { June }\end{array}$ & $\begin{array}{l}\text { North- } \\
\text { central } \\
\text { Oklahoma }\end{array}$ & Late & $\begin{array}{l}\text { nc (year 1) } \\
\text { nc (year 2) }\end{array}$ & $\begin{array}{c}-(\text { year 1) } \\
\text { nc (year 2) }\end{array}$ & $\begin{array}{c}-(\text { year 1) } \\
\text { nc (year 2) }\end{array}$ & $\begin{array}{l}+(\text { year } 1) \\
+(\text { year } 2)\end{array}$ & $\begin{array}{c}+(\text { year 1) } \\
\text { nc (year 2) }\end{array}$ & $\begin{array}{l}\text { nc (year 1) } \\
\text { nc (year 2) }\end{array}$ & $\begin{array}{l}\text { Burned in } 1985 . \\
\text { Ungrazed. } \\
10,300 \mathrm{~kg} / \text { ha fuel. }\end{array}$ & $\begin{array}{l}\text { Ewing and } \\
\text { Engle } \\
(1988) . \\
\text { Engle et al. } \\
(1992)\end{array}$ \\
\hline $\begin{array}{l}\text { Late summer } \\
\text { (September 5) } \\
\text { Measured in } \\
\text { August, Year } 1\end{array}$ & $\begin{array}{l}\text { North- } \\
\text { central } \\
\text { Oklahoma }\end{array}$ & Mid & $\mathrm{nc}$ & $\mathrm{nc}$ & $\mathrm{nc}$ & $\mathrm{nc}$ & $\mathrm{nc}$ & $\mathrm{nc}$ & $\begin{array}{l}\text { Burned in } 1985 . \\
\text { Moderately grazed } \\
4400 \mathrm{~kg} / \text { ha fuel. }\end{array}$ & $\begin{array}{l}\text { Ewing and } \\
\text { Engle } \\
(1988) . \\
\text { Engle et al. } \\
(1992)\end{array}$ \\
\hline $\begin{array}{l}\text { Late summer } \\
\text { (September 5) } \\
\text { Measured } \\
\text { August }\end{array}$ & $\begin{array}{l}\text { North- } \\
\text { central } \\
\text { Oklahoma }\end{array}$ & Late & $\mathrm{nc}$ & $\mathrm{nc}$ & - & $\mathrm{nc}$ & $\mathrm{nc}$ & $\mathrm{nc}$ & $\begin{array}{l}\text { Burned in } 1985 . \\
\text { Ungrazed } \\
10,300 \mathrm{~kg} / \mathrm{ha} \text { fuel }\end{array}$ & $\begin{array}{l}\text { Ewing and } \\
\text { Engle } \\
\text { (1988), } \\
\text { Engle et al. } \\
\text { (1992). }\end{array}$ \\
\hline $\begin{array}{l}\text { Late summer } \\
\text { (September) }\end{array}$ & $\begin{array}{l}\text { North- } \\
\text { central } \\
\text { Oklahoma }\end{array}$ & Late & nc & $\begin{array}{c}-(\text { year } 1) \\
\text { nc (year 2) }\end{array}$ & $\begin{array}{l}-(\text { year } 1) \\
-(\text { year } 2)\end{array}$ & $\begin{array}{c}\text { Not } \\
\text { reported }\end{array}$ & $\begin{array}{c}\text { Not } \\
\text { reported }\end{array}$ & $\begin{array}{l}\text { Not } \\
\text { reported }\end{array}$ & $\begin{array}{l}\text { Burned in } 1988 \\
\text { and } 1989 . \text { Plots burned } \\
\text { in moderately grazed } \\
\text { pasture. } 8,200 \mathrm{~kg} / \mathrm{ha} \\
\text { fuel. Forb production } \\
\text { was highly variable } \\
\text { among treatment plots. }\end{array}$ & $\begin{array}{l}\text { Engle et al. } \\
\text { (1993) }\end{array}$ \\
\hline $\begin{array}{l}\text { Late summer } \\
\text { to early fall } \\
\text { (Early August } \\
\text { to early October }\end{array}$ & $\begin{array}{l}\text { South- } \\
\text { central } \\
\text { r) }\end{array}$ & Mid & $\begin{array}{c}\text { Loamy } \\
- \\
\text { Shallow } \\
\text { nc }\end{array}$ & $\mathrm{nc}$ & $\begin{array}{c}\text { Loamy } \\
- \\
\text { Shallow } \\
\text { nc }\end{array}$ & + & $\begin{array}{l}\text { Not } \\
\text { reported }\end{array}$ & $\begin{array}{l}\text { Not } \\
\text { reported }\end{array}$ & $\begin{array}{l}\text { Burned } 2 \text { sites } \\
\text { (shallow and loamy) } \\
\text { up to } 3 \text { times in } 5 \\
\text { years. Not grazed the } \\
\text { year of the first burn and } \\
\text { after for the duration of } \\
\text { the study. Prairie three- } \\
\text { awn abundant at the time } \\
\text { of the first burn. Respons } \\
\text { reported for only first } \\
\text { burn. }\end{array}$ & $\begin{array}{l}\text { Engle et al. } \\
(1998) \\
\text { d } \\
\text { e } \\
\text { ise }\end{array}$ \\
\hline
\end{tabular}

$+=$ increase, $-=$ decrease, $n c=$ no difference $(\mathrm{P}>0.05)$ as compared to unburned checks or pre-burn.

Owensby, unpublished) suggesting that weather conditions can have an overriding influence on response to fire.

Burns in the early dormant season may concomitantly increase forbs, including western ragweed (Ambrosia psilostachya DC.) (Hopkins et al. 1948), but western ragweed does not compete with grasses and appears to fluctuate independent of grass production (Launchbaugh 1969, Vermiere 1997). Moreover, an increase in forbs does not appear universal following early dormant-season burns. Burning mixed prairie in late January with the objective of increasing forb production, primarily western ragweed, did not increase forb production nor reduce grass production in northwestern Oklahoma on sandy soils (Peoples et al. 1994).

\section{Appropriate Management after Fire}

This review of research on post-burn vegetation response in Oklahoma and Kansas native grasslands suggests a wide variety of responses are possible, and rules-of-thumb that generalize responses to wildfire may be misleading. Launchbaugh and Owensby (1978) recommended reducing stocking rate on areas burned by wildfire in Kansas by 25 to $75 \%$ the first year and 25 to $50 \%$ the second year after the fire. A more recent recommendation is to reduce stocking rate by 15 to $25 \%$ in the tallgrass prairie and by $50 \%$ in mixed prairie (Ohlenbusch 1992). These recommendations have been applied throughout Oklahoma and Kansas to native grasslands 
burned by wildfire. Furthermore, as an extension to the common practice of applying herbicides at regular intervals to reduce forbs and favor grasses (New 1997), managers often apply herbicide the growing season following wildfire in expectation of an increase in forbs. The results from the published studies we present here suggest grassland environments in Oklahoma and Kansas are too diverse for these recommendations to apply uniformly.

A number of factors can alter the effects of early dormant-season and growing-season fires on species composition and herbage production in native grasslands and should be considered when adjusting stocking rate or deciding on whether to apply a broadleaf herbicide. Successional stage at the time of a fire is perhaps the most important factor influencing post-fire species composition. However, most studies on the effects of fire in Oklahoma and Kansas grasslands have been conducted in late seral vegetation in which forbs were a minor component of the vegetation. It is logical to assume that if abundant before fire, forbs should increase after fire if the fire reduces the competitiveness of other species and if the timing is not coincident with a susceptible stage of development of the forbs in question (Howe 1994). Conversely, if forbs are scarce because of moderate-continuous stocking, a history of late dormant-season fire, or previous use of broadleaf herbicides, then forbs probably will not increase with early dormant-season fire.

Post-fire observations of native grasslands in early and mid successional stages as well as confounding factors such as post-fire grazing practices may be the source of some of the conventional wisdom that early season fire increases forb abundance. We think preferential livestock grazing of a burned area in a partially burned pasture has caused many managers to misinterpret the effects of wildfire. When making decisions on stocking rate or herbicide applications after wildfire, rangeland managers should also consider the pre- and post-fire growing conditions and the exact timing of the fire relative to growth stage of key species. Species composition and standing crop (which influences fire behavior) at the time of the fire, soil texture and site potential, pre- and post-fire management (grazing management, herbicide use, fertilization, prescribed burning, and others), and land use history (grazing, cultivation, and others) also confound the influence of fire on species composition and should be taken into account in post-fire management.

\section{Conclusions}

It was once held firmly by Oklahoma scientists that fire in any season and in any climate decreased plant production and increased weedy species unpalatable to livestock (for example, see Bunch et al. 1958). This kind of response to fire follows preferential grazing of the burned areas that offer more palatable forage to livestock and is in reality the result of overstocking (Launchbaugh and Owensby 1978). In one of the first controlled studies involving livestock grazing on areas with a mixture of burned and unburned areas, Penfound and Kelting (1950) noted that virtually no grass leaves were grazed in the unburned areas. Studies now in place at several locations in the central Great Plains are investigating the influence of fire at varied seasons and spatial contexts on ecosystem responses to include large herbivores allowed to preferentially graze burned patches within a matrix of unburned native grassland (e.g., Coppedge et al. 1998a, 1998b). The early indications suggest that these grasslands are far more productive and resilient under fire and preferential spot grazing than earlier believed.

How, then, should a manager respond to a fire timed at a season or date with which the manager is unaccustomed? Many rangeland managers, especially in Oklahoma, are unaccustomed to fire in any season and have never burned their rangelands, so that the consequences of any fire are unknown to the manager. An adjustment in stocking rate of domestic livestock is likely the prudent course of action, but understocking for more than 1 or 2 years is likely unwarranted especially in the more mesic regions of Oklahoma and Kansas. Of course, appropriate post-fire management also depends on current weather conditions, intrinsic managerial options (e.g., herd composition and flexibility), and management objectives. Managerial attentiveness must therefore be at its highest to respond to the range of possible responses of native grasslands to fire.

We conclude that a variety of composition and production responses to season of fire are possible, and that the native grasslands of Kansas and Oklahoma are more resilient to burning in any season than is commonly held by conventional wisdom. Moreover, the body of literature suggests that broadly applied rules-of-thumb cannot be constructed for post-fire management regardless of the season. Thus, the only objective, accurate method to assess the relatively minor effects of fire (wildfire or prescribed fire) in any season is to measure the vegetation after fire. Although rules-ofthumb appear valid for dormant-season fires in the late-seral tallgrass prairies of the northern Flint Hills, the body of literature indicates we cannot at this time accurately predict vegetation response in other seasons and other locations.

\section{Literature Cited}

Abrams, M.D., A.K. Knapp, and L.C. Hulbert. 1986. A ten-year record of aboveground biomass in a Kansas tallgrass prairie: Effects of fire and topographic position. Amer. J. Bot. 73:1509-1515.

Adams, D.E. and R.C. Anderson. 1978. The response of a central Oklahoma grassland to burning. Southwest. Natur. 23:623-632.

Adams, D.E., R.C. Anderson, and S.L. Collins. 1982. Differential response of woody and herbaceous species to summer and winter burning in an Oklahoma grassland. Southwest. Natur. 27:55-61.

Anderson, K.L., C.E. Owensby, and E.F. Smith. 1970. Burning bluestem range. J. Range Manage. 23:81-92.

Bidwell, T.G., D.M. Engle, and P.L. Claypool. 1990. Effects of spring headfires and backfires on tallgrass prairie. J. Range Manage. 43:209-212.

Blair, J.M. 1997. Fire, N availability, and plant response in grasslands: a test of the transient maxima hypothesis. Ecol. 78:2359-2368.

Bragg, T.B. 1982. Seasonal variations in fuel and fuel consumption by fires in a bluestem prairie. Ecol. 63:7-11.

Bragg, T.B. 1995. The physical environment of the Great Plains grasslands. pp. 49-81, In: A. Joern and K.H. Keeler (eds.). The changing prairie-North American grasslands. Oxford Univ. Press. New York.

Briggs, J.M. and A.K. Knapp. 1995. Interannual variability in primary production in tallgrass prairie: Climate, soil moisture, topographic position, and fire as determinants of aboveground biomass. Amer. J. Bot. 82:1024-1030.

Bunch, C., E. Roberts, and R.E. Chiles. 1958. Stop grass fires. Oklahoma State Univ. Ext. Serv. Leaflet L-32.

Collins, S.L., A.K. Knapp, J.M. Briggs, J.M. Blair, and E.M. Steinauer. 1998. Modulation of diversity by grazing and mowing in native tallgrass prairie. Sci. 280:745-747.

Coppedge, B.R., D.M. Engle, C.S. Toepfer, and J.H. Shaw. 1998a. Effects of seasonal fire, bison grazing and climatic variation on tallgrass prairie vegetation. Plant Ecol. 139:235-246.

Coppedge, B.R, D.M. Leslie, Jr., and J.H. Shaw. 1998b. Botanical composition of bison diets on tallgrass prairie in Oklahoma. J. Range Manage. 379-382.

Elwell, H.M., H.A. Daniel, and F.A. Fenton. 1941. The effects of burning pasture and woodland vegetation. Oklahoma Agr. Exp. Sta. B-247. 
Engle, D.M., T.G. Bidwell, J.F. Stritzke, and D. Rollins. 1990. Atrazine and burning in tallgrass prairie infested with prairie threeawn. J. Range Manage. 43:424-427.

Engle, D.M., T.G. Bidwell, and A.L. Ewing. 1992. Effects of late summer fire in tallgrass prairie. p. 9 In: T.G. Bidwell (ed.). Range research highlights. Coop. Ext. Serv. Oklahoma State Univ. Circ. E-905, Stillwater.

Engle, D.M., M.W. Palmer, J.S. Crockett, R.L. Mitchell, and R. Stevens. 2000 . Influence of late season fire on an early successional Oklahoma prairie. J. Veg. Sci. 11:135-144.

Engle, D.M., J.F. Stritzke, T.G. Bidwell, and P.L. Claypool. 1993. Late-summer fire and follow-up herbicide treatments in tallgrass prairie. J. Range Manage. 542-547.

Engle, D.M., R.L. Mitchell, and R.L. Stevens. 1998. Growing-season fire effects on forage production in mid-successional tallgrass prairie. J. Range Manage. 51:115-121.

Ewing, A.L. and D.M. Engle. 1988. Effects of late summer fire on tallgrass prairie microclimate and community composition. Amer. Midl. Natur. 120:212-223.

Gibson, D.J. 1989. Hulbert's study of factors effecting botanical composition of tallgrass prairie. Proc. $11^{\text {th }}$ North Amer. Prairie Conf. pp. 115-133.

Gibson, D.J. and L.C. Hulbert. 1987. Effects of fire, topography and year-to-year climatic variation on species composition in tallgrass prairie. Vegetatio 72:175-185.

Graves, J.E. and W.E. McMurphy. 1969. Burning and fertilization for range improvement in central Oklahoma. J. Range Manage. 22:165-168.

Higgins, K.F. 1986. Interpretation and compendium of historical fire accounts in the Northern Great Plains. U.S. Fish and Wildl. Serv. Res. Publ. 161.

Hopkins, H.F., F.W. Albertson, and A. Riegel. 1948. Some effects of burning upon a prairie in west-central Kansas. Trans. Kan. Acad. Sci. 51:131-141.

Howe, H.F. 1994. Response of early- and lateflowering plants to fire season in experimental prairies. Ecol. Appl. 4:121-133

Hulbert, L.C. 1969. Fire and litter effects in undisturbed bluestem prairie in Kansas. Ecol. 50:874-877.

Hulbert, L.C. 1988. The causes of fire effects in tallgrass prairie. Ecol. 69:46-58.

James, S.W. 1985. An unexpected effect of autumn burning in tallgrass prairie. Amer Midl. Natur. 114:400-403.

Kelting, R.W. 1957. Winter burning in central Oklahoma grassland. Ecol. 38:520-523.

Knapp, A.K. 1984. Post-burn differences in solar radiation, leaf temperature and water stress influencing production in a lowland tallgrass prairie. Amer. J. Bot. 71:220-227.

Kucera, C.L. and J.H. Ehrenreich. 1962 Some effects of annual burning on central Missouri prairie. Ecol. 43:334-336.

Launchbaugh, J.L. 1964. Effects of early spring burning on yields of native vegetation. J. Range Manage. 17:5-6.
Launchbaugh, J.L. 1969. Range condition classification based on regressions of herbage yields on summer stocking rates. J. Range Manage. 22:97-101.

Launchbaugh, J.L. 1978. Effects of fire on shortgrass vegetation. Proc. Prairie Prescribed burning Symp. and Workshop. 25 Apr. 1978. Northern Prairie Wildl. Res. Center, Jamestown, N. D.

Launchbaugh, J.L. and C.E. Owensby. 1978. Kansas rangelands: their management based on a half century of research. Kansas Agr. Exp. Sta. Bull. 622. Manhattan, Kans.

McMurphy, W.E. and K.L. Anderson. 1963. Burning bluestem range-forage yields. Kans. Acad. Sci. Trans. 66:49-51.

McMurphy, W.E. and K.L. Anderson. 1965. Burning Flint Hills range. J. Range Manage. 18:265-269.

Mitchell, R.B., R.A. Masters, S.S. Waller, K.J. Moore, and L.J. Young. 1996. Tallgrass prairie vegetation response to spring burning dates, fertilizer, and atrazine. J. Range Manage. 49:131-136.

New, M.G. 1997. Survey of weed management practices in pastures and rangelands in Oklahoma and selectivity of various herbicide treatments on cultivars of forage bermudagrass (Cynodon dactylon). M.S. Thesis. Oklahoma State Univ. Stillwater, Okla.

Ohlenbusch, P.D. 1992. Management following wildfire. Kansas Coop. Ext. Serv. L-514 (revised). Manhattan, Kans.

Old, S.M. 1969. Microclimate, fire and plant production in an Illinois prairie. Ecol. 39:355-384.

Owensby, C.E. and K.L. Anderson. 1967. Yield responses to time of burning in the Kansas Flint Hills. J. Range Manage. 20:12-16.

Owensby, C.E. and J.L. Launchbaugh. 1977. Controlling prairie threeawn (Aristida oligantha Michx.) in central and eastern Kansas with fall burning. J. Range Manage. 30:337-339.

Penfound, W.T. and R.W. Kelting. 1950. Some effects of winter burning on a moderately grazed pasture. Ecol. 31:554-560.

Peoples, A.D., R.L. Lochmiller, D.M. Leslie, Jr., and D.M. Engle. 1994. Producing northern bobwhite food on sandy soil in semiarid mixed prairies. Wildl. Soc. Bull. 22:204-211.

Powell, J., H.T. Zawi, J.J. Crockett, L.I. Croy, and R.D. Morrison. 1979. Central Oklahoma rangeland response to fire, fertilization, and grazing by sheep. Oklahoma Agr. Exp. Sta. Bull. B-744.

Rice, E.L. 1971. Inhibition of nodulation on inoculated legumes by leachates from pioneer plant species from abandoned fields. Amer. J. Bot. 58:368-371.

Rice, E.L. and R.L. Parenti. 1978. Causes of decreases in productivity in undisturbed tall grass prairie. Amer. J. Bot. 65:1091-1097.

Riggs, R.A., S.C. Bunting, and S.E. Daniels. 1996. Prescribed fire, pp. 295-319 In: P.R. Krausman (ed.). Rangeland Wildlife. Soc. Range Manage. Denver, Colo.
Roberts, K.W., D.M. Engle, and J.R. Weir. 1999. Weather constraints to scheduling prescribed burns. Rangelands 21:6-7.

Smith, E.F. and C.E. Owensby. 1972. Effects of fire on true prairie grasslands. Proc. Tall Timbers Fire Ecology Conf. 12:9-22.

Towne, E.G. and A.K. Knapp. 1996. Biomass and density responses in tallgrass prairie legumes to annual fire and topographic position. Amer. J.. Bot. 83:175-179.

Towne, G. and C. Owensby. 1984. Long-term effects of annual burning at different dates in ungrazed Kansas tallgrass prairie. J. Range Manage. 37:392-397.

Vermiere, L. 1997. Western ragweed growth and competitiveness on mixed and tallgrass prairie. M.S. Thesis. Oklahoma State Univ.

Zimmerman, J.L. 1997. Avian responses to fire, grazing, and drought. pp. 167-180, In: F.L. Knopf and F.B. Samson (eds.). Ecology and conservation of Great Plains vertebrates. Ecological Studies, Vol. 125. Springer. New York. 